\title{
Perception of Professionalism of Medical Undergraduate Students of Tadulako University by Grade
}

\author{
Indah Puspasari Kiay Demak ${ }^{1,2 *}$, Ria Sulistiana ${ }^{3}$, Andrew $^{4}$, Sindi Safira $^{4}$ \\ ${ }^{1}$ Medical Education Unit, Medical Faculty, Tadulako University \\ ${ }^{2}$ Department of Public Health and Community Medicine, Medical Faculty, Tadulako University \\ ${ }^{3}$ Department of Radiology, Medical Faculty, Tadulako University \\ ${ }^{4}$ Medical Faculty, Tadulako University \\ *Corresponding author. Email: sashkata@yahoo.com
}

\begin{abstract}
Introduction. The medical profession demands are increasingly high, along with the medical education institutions' needs producing competent doctors who are ready to perform the best medical services in the future. One of the indicators of the competence of a doctor is to become a professional. A doctor needs to be competent in knowledge, skills and also have to be professional.

Methods. This was an analytical observational study with a cross-sectional approach. The subject was 565 undergraduate medical students of Tadulako University. Respondents were completed an online questionnaire about the perspective of professionalism, which comprises 20 questions about commitment to self, commitment to patients, commitment to profession, and commitment to society. The comparative Kruskal-Wallis test analyzed data.

Results. In preclinical students, the first year's perception of professionalism is higher than in the upper-year in all categories. The highest mean perception score is in the category commitment to patient, and the lowest value is on commitment to society. There was no significant difference between student grades and perceived professionalism in all categories ( $p$ value> 0.05). In clinical students, there is a trend of increasing the value of the perception of professionalism in all categories. Meanwhile, the mean scores in all categories are almost the same. There was a significant difference between the perception of professionalism and grade ( $\mathrm{p}$-value $<0.05$ ).

Conclusion. In preclinical students, perception scores tend to decrease with increasing years of education. On the other hand, there was an increase in clinical students from the first year to the third year.
\end{abstract}

Keywords: professionalism, perception, undergraduate, medical students.

\section{INTRODUCTION}

The medical profession demands are increasingly high, along with the needs of the medical education institutions producing competent doctors who are ready to perform the best medical services in the future. One of the indicators of the competence of a doctor is to become a professional. A doctor needs to be competent in knowledge, skills and also have to be professional [1].

Professionalism refers to the collection of abilities and principles that in professional practice define the essence of humanism in the medical practice [2]. Crues et. al. [3] divided the medical professional's attributes into two, namely healer and professional, which are also called dual roles. Attributes of the healer relate to the role of a doctor in dealing with patients. Simultaneously, the professional attributes are other modern professional attributes that have not been linked with the traditional healing role. Royal College of Physician and Surgery of Canada (CanMEDS) divides professionalism into four, namely, commitment to society, commitment to patients, commitment to the profession, and commitment to self [4].

The teaching model of professionalism varies from institution to institution. Some institutions develop 
professionalism curricula by including them into compulsory material. Some of them only convey theories about professionalism in the form of lectures. In contrast, others combine the material in an integrated manner in tutorial discussions and medical skills practicum. While other institutions adopt several innovative methods for students to help in forming a professional identity, such as in the form of simulations, theater, narrative essays, portfolios, and in the form of recollection reports. Medical professionalism learning can collaborate in several learning methods [5]-[9].

This study aims to know the difference in perception of professionalism between grades on undergraduate medical students.

\section{METHODS}

This was an analytical observational study with cross sectional approach. The subject were 565 undergraduate medical students of Tadulako University. Convenience sampling technique was used in selecting the subjects. Ethical clearance has been obtained from The Ethics Committee of Medical Faculty of Tadulako University (No. 4926/UN.28.1.30/KL/220) before collecting the data. Respondents were completed an online questionnaire about perspective of professionalism which comprise of 20 questions. The questionnaire was developed based on attributes of professionalism on The Royal College of Physician and Surgery of Canada (CanMEDS), which is categorized into four, namely, commitment to society, commitment to patients, commitment to the profession, and commitment to self. Commitment to society includes commitment promoting the public good in health care, social accountability, the social contract in health care, and societal expectation of physicians and the profession. Commitment to the profession comprises accountability to professional regulatory authorities, codes of ethics, patient safety, commitment to professional standards, and responsibility to the profession. Commitment to patient consists of altruism, excellence, compassion and caring, confidentiality, integrity and honesty, and respect. Moreover, commitment to self includes mindful and reflective, responsible to self (personal care), and self- regulation [4]. The data were analyzed by the comparative Kruskal-Wallis test.

\section{RESULTS}

The medical program at Tadulako University consists of a preclinical and clinical stage. The preclinical stage is implemented for 3,5 years. It used competence based curriculum which is divided into organ system modules. Procedural skills, research, and professional development are integrated within curriculum. After accomplishing this program, students will receive their bachelor's degree. The clinical stage is completed in 2 years minimal. It is a hospital based and primary health care center based. The curriculum based on clinical expertise. After completing this phase, students will receive their professional degree as a medical doctor.

Table 1. Subject characteristics

\begin{tabular}{|c|c|c|c|}
\hline \multicolumn{2}{|c|}{ Characteristic } & $\begin{array}{c}\text { Precinical } \\
\text { students } \\
(\mathbf{N = 3 0 7})\end{array}$ & $\begin{array}{c}\text { Clinical } \\
\text { students } \\
\text { (N=158) }\end{array}$ \\
\hline Age (Mean \pm SD) & $19.58 \pm 1.05$ & $22.97 \pm 1.24$ \\
\hline Sex & Male & $108(35.2 \%)$ & $67(42.4 \%)$ \\
& Female & $199(64.8 \%)$ & $91(57.6 \%)$ \\
\hline Year & I & $130(42.35 \%)$ & $63(39.9 \%)$ \\
\hline & II & $103(33.55 \%)$ & $67(42.4 \%)$ \\
\hline & III & $74(24.10 \%)$ & $28(17.7 \%)$ \\
\hline
\end{tabular}

The research subjects consisted of 307 preclinical students and 158 clinical phase students. The response rate for filling out the questionnaire was $73.98 \%$ for preclinical students and $49.36 \%$ for clinical students.

Table 2. Learning resources of professionalism

\begin{tabular}{|c|c|c|c|c|}
\hline \multirow[t]{2}{*}{ Stage } & \multicolumn{4}{|c|}{ Learning resources } \\
\hline & Lecture & Book & $\begin{array}{c}\text { Role } \\
\text { model }\end{array}$ & Movie \\
\hline $\begin{array}{l}\text { Preclinic } \\
\text { al } \\
\text { students }\end{array}$ & $\begin{array}{l}203 \\
(66.12 \% \\
)\end{array}$ & $\begin{array}{l}133 \\
(43.32 \% \\
)\end{array}$ & $\begin{array}{l}112 \\
(36.48 \% \\
)\end{array}$ & $\begin{array}{l}112 \\
(36.48 \% \\
)\end{array}$ \\
\hline $\begin{array}{l}\text { Clinical } \\
\text { students }\end{array}$ & $\begin{array}{l}125 \\
(79.11 \% \\
)\end{array}$ & $\begin{array}{l}79 \\
(50 \%)\end{array}$ & $\begin{array}{l}108 \\
(68.35 \% \\
)\end{array}$ & $\begin{array}{l}54 \\
(34.17 \% \\
)\end{array}$ \\
\hline
\end{tabular}

Learning sources about professionalism in preclinical students are mostly obtained from lectures, 
while professional students are obtained apart from lectures and from clinical supervisor lecturer role models.

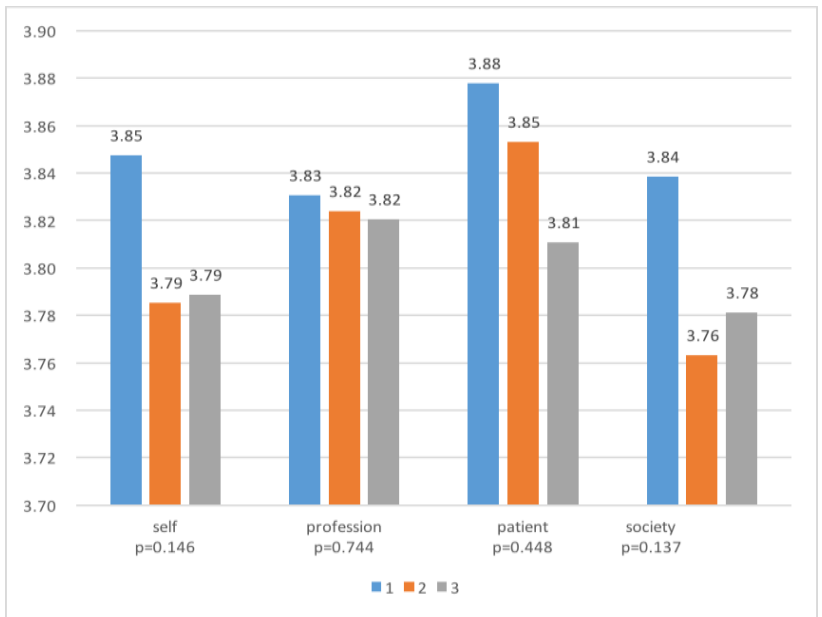

Figure 1. The differences of perception on preclinical phase students (Kruskal-Wallis test)

Overall, the perception of professionalism in first-year students is higher than in the upper-year in all categories (Figure 1). The highest average perception score is in the category commitment to patient, and the lowest value is on commitment to society. The second-year students have higher perception score in the category of commitment to profession and patients than the third-year students. Moreover, in the category of commitment to self and society, third-year students have a higher perception score than second-year students. Based on the Kruskal-Wallis comparative test, it was found that there was no significant difference between student grades and perceived professionalism in all categories (p value $>0.05$ )

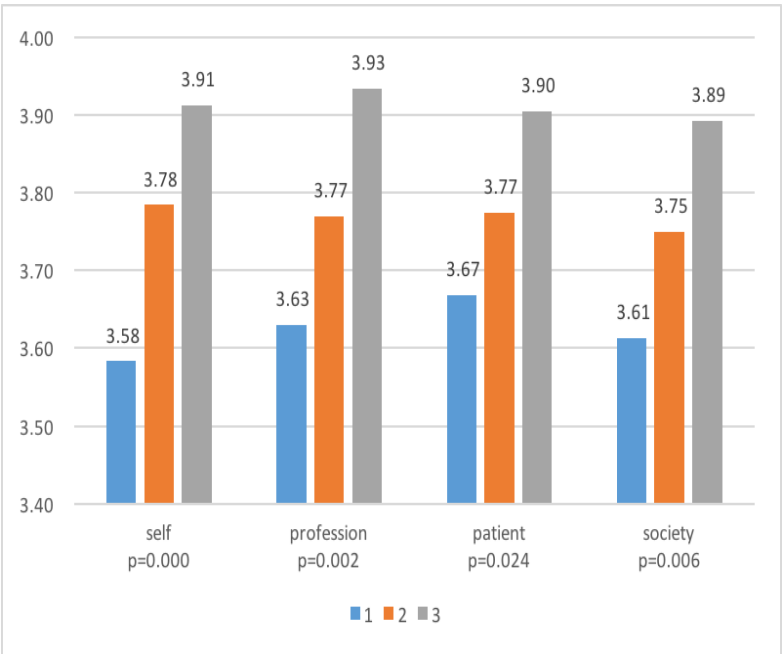

Figure 2. The differences of perception on clinical phase students (Kruskal-Wallis test)

Figure 2 presented a trend of increasing the value of the perception of professionalism in all categories by grades. Meanwhile, the average scores in all categories are almost the same. Based on the KruskalWallis comparative test, there was a significant difference between the perception of professionalism and grade ( $\mathrm{p}$-value $<0.05$ ).

\section{DISCUSSION}

This study aims to compare perceptions of professionalism according to the grade of students in preclinical and clinical students. There was no significant difference in the perception of professionalism between first, second, and third-year students (p-value $>0.05$ ) in all categories in preclinical students. There is a tendency, first-year students to have higher perception and a decrease in the second and third years.

First-year students have positive attitudes towards professionalism, although they still have a minimum understanding of professionalism, especially in implementation [10]. Reimer et al.[11] stated that first-year and second-year students are familiar with professionalism, especially towards a doctor's figure, even though they are still exposed to minimal exposure to the professionalism curriculum, especially for first-year students. This is because even before becoming medical students, they had imagined what a doctor would be like. As experience increases as medical students, the perception of professionalism 
also decreases because they know the conditions of doctors' reality. This can be obtained from lectures and role models, especially on the commitment to patient and profession. Meanwhile, there was a slight increase in the perception score from the second year to the third year on the aspect of commitment to self and society.

Furthermore, the perceived value of commitment to society tends to be of lower value than other aspects of professionalism. This could be because students do not feel the social responsibility towards society. Because in the preclinical phase, they have not had much interaction with the community. The trend of perceptual scores that decreases along with the increase in education grade in preclinical students is due to the experiences they have experienced during their education, especially role models and the faculty environment that does not support the development of professionalism so that there is a decrease in assessment [12], [13]

In clinical students, there was a significant difference in the perception of professionalism between first, second, and third-year students ( $\mathrm{p}$-value $<0.05)$ in all categories. Perceptions of professionalism increase with increasing years. Klemenc-Ketis [14] get the same results, namely, fifth-year students view a more comprehensive range of attributes of professionalism and more self-centered perception of medical doctor figures. There is an increase in the perception of professionalism, and the increasing years of education due to the longer studying means that the more students know their role as doctors. Likewise, when the level of education increases, the assessment of professionalism will increase. For example, the scores for perceived professionalism among residents tend to be higher than for clinical undergraduate students [15].

Learning about professionalism is indeed very challenging. The faculty's support is significant in creating a supportive learning environment so that students can understand more about professionalism. Positive role modeling of lecturers is an essential aspect.

\section{CONCLUSION}

In preclinical students, perception scores tend to decrease with increasing years of education. On the other hand, there was an increase in clinical students from the first year to the third year. Perception towards professionalism are related to the students' prior knowledge about doctor's figure, lectures, role models, and experiences in the hospital or in the community.

\section{REFERENCES}

[1] Konsil Kedokteran Indonesia, "Standar Kompetensi Dokter Indonesia 2019," 2019.

[2] L. Vivanco and R. Delgado-Bolton, "Professionalism," in Encyclopedia of Global Bioethics, Springer Link, 2019.

[3] R. L. Cruess, S. R. Cruess, and Y. Steinert, Teaching Medical Professionalism. New York: Cambridge University Press, 2009.

[4] Royal College of Physician and Surgeons of Canada, "Proessional," 2020. https://www.royalcollege.ca/rcsite/canmeds/fr amework/canmeds-role-professional-e (accessed Nov. 26, 2020).

[5] H. S. Wald, J. M. Borkan, J. S. Taylor, D. Anthony, and S. P. Reis, "Fostering and evaluating reflective capacity in medical education: Developing the REFLECT rubric for assessing reflective writing," Acad. Med., vol. 87, no. 1, pp. 41-50, 2012, doi: 10.1097/ACM.0b013e31823b55fa.

[6] D. S. Hatem and T. Halpin, "Becoming Doctors: Examining Student Narratives to Understand the Process of Professional Identity Formation Within a Learning Community," J. Med. Educ. Curric. Dev., vol. 6, p. 238212051983454, 2019, doi: $10.1177 / 2382120519834546$.

[7] M. Schweller, D. L. Ribeiro, E. V. Celeri, and M. A. de Carvalho-Filho, "Nurturing virtues of the medical profession: does it enhance medical students' empathy?," Int. J. Med. Educ., vol. 8, pp. 262-267, 2017, doi: 10.5116/ijme.5951.6044.

[8] M. A. De Carvalho Filho et al., "Medical Education Empowered by Theater (MEET)," Acad. Med., vol. 95, no. 8, pp. 1191-1200, 2020, doi: 10.1097/ACM.0000000000003271.

[9] H. Birden, N. Glass, I. Wilson, M. Harrison, T. Usherwood, and D. Nass, "Teaching professionalism in medical education: A Best Evidence Medical Education (BEME) systematic review. BEME Guide No. 25," Med. Teach., vol. 35, no. 7, 2013, doi: 
10.3109/0142159X.2013.789132.

[10] M. V. Kavas, M. Demirören, A. M. A. Koşan, S. T. Karahan, and N. Y. Yalim, "Turkish students' perceptions of professionalism at the beginning and at the end of medical education: A cross-sectional qualitative study," Med. Educ. Online, vol. 20, no. 1, 2015, doi: 10.3402/meo.v20.26614.

[11] D. Reimer et al., "Pre-clerkship medical students' perceptions of medical professionalism," BMC Med. Educ., vol. 19, no. 1, pp. 1-9, 2019, doi: 10.1186/s12909019-1629-4.

[12] B. Serrano-costa, D. Flores-funes, C. Botellamartínez, N. M. Atucha, and J. García-estañ, "MEDICAL PROFESSIONALISM PERCEPTION," vol. 3, no. 3, pp. 0-2, 2020.

[13] T. AlMahmoud, M. Jawad Hashim, M. A. Elzubeir, and F. Branicki, "Ethics teaching in a medical education environment: preferences for diversity of learning and assessment methods," Med. Educ. Online, vol. 22, no. 1, p. 1328257, 2017, doi: 10.1080/10872981.2017.1328257.

[14] Z. Klemenc-Ketis and H. Vrecko, "The perceptions of professionalism by 1 st and 5th grade medical students," Acta Inform. Medica, vol. 22, no. 5, pp. 292-296, 2014, doi: 10.5455/aim.2014.22.292-296.

[15] M. K. Morreale, R. Balon, and C. L. Arfken, "Survey of the importance of professional behaviors among medical students, residents, and attending physicians," Acad. Psychiatry, vol. 35, no. 3, pp. 191-195, 2011, doi: 10.1176/appi.ap.35.3.191. 